\title{
Meloxicam decreases the migration and invasion of CF41.Mg canine mammary carcinoma cells
}

\author{
MARÍA P. ITURRIAGA ${ }^{1}$, RODOLFO PAREDES $^{2}$, JOSE I. ARIAS $^{3}$ and CRISTIAN G. TORRES ${ }^{3}$ \\ ${ }^{1}$ Laboratory of Ecosystem Health and ${ }^{2}$ School of Veterinary Medicine, Faculty of Ecology and Natural Resources, \\ Universidad Andres Bello, Santiago 8370251; ${ }^{3}$ Laboratory of Biomedicine and Regenerative Medicine, Department of \\ Clinical Sciences, Faculty of Veterinary and Animal Sciences, University of Chile, Santiago 8820808, Chile
}

Received August 23, 2016; Accepted March 3, 2017

DOI: $10.3892 / \mathrm{ol} .2017 .6400$

\begin{abstract}
Cyclooxygenase (COX)-2 expression is positively correlated with malignant features in canine mammary carcinomas. Non-steroidal anti-inflammatory drugs (NSAIDs) inhibit COX activity and may therefore possess anticancer effects. Meloxicam is an NSAID that is widely used in human and veterinary medicine. High concentrations of meloxicam have been reported to be antitumorigenic in vitro; however, the effect of meloxicam at concentrations that are equivalent to those that can be obtained in vivo remains unknown. In the current study, the in vitro effects of low-dose meloxicam $(0.25 \mu \mathrm{g} / \mathrm{ml})$ on CF41.Mg canine mammary carcinoma cells were evaluated. The effects on cell proliferation, apoptosis, cell migration and invasion, in addition to the expression of different molecules associated with tumor invasiveness were analyzed. No effect on cell viability and apoptosis were observed. However, cell migration and invasion were significantly reduced following treatment with meloxicam. MMP-2 expression and activity were similarly reduced, explaining the impaired cell invasion. In addition, $\beta$-catenin expression was downregulated, while its phosphorylation increased. These results indicate that $0.25 \mu \mathrm{g} / \mathrm{ml}$ meloxicam reduces cell migration and invasion, in part through modulating MMP-2 and $\beta$-catenin expression. Additional studies are required to elucidate the mechanism associated with the anti-invasive effect of meloxicam on CF41.Mg cells. The results of the present study suggest that meloxicam has a potential adjunctive therapeutic application, which could be useful in controlling the invasion and metastasis of canine mammary carcinomas.
\end{abstract}

Correspondence to: Dr Cristian G. Torres, Laboratory of Biomedicine and Regenerative Medicine, Department of Clinical Sciences, Faculty of Veterinary and Animal Sciences, University of Chile, 11735 Santa Rosa Avenue, Santiago 8820808, Chile E-mail: crtorres@uchile.cl

Key words: cyclooxygenase-2, meloxicam, canine mammary carcinoma, cell invasion

\section{Introduction}

Mammary tumors are the most common malignancy in reproductively intact female dogs (1). Malignant neoplasms represent $\sim 50 \%$ of total mammary tumors in canines, and $\sim 50 \%$ of these have already metastasized at the time of clinical diagnosis (2). The enzyme cyclooxygenase (COX) controls the synthesis of prostaglandins (PG) from arachidonic acid (3). COX-2, an inducible form of COX, has been associated with carcinogenesis, cell proliferation, resistance to apoptosis, tumor tissue invasion, immunosuppression and angiogenesis (4,5). Several previous studies have suggested an association between COX-2 expression and the progression of various human $(6,7)$ and canine $(8,9)$ types of cancer. In addition, high COX-2 expression has been documented in canine mammary carcinoma and associated with tumor malignancy $(10,11)$. There is known to be an association between cancer cell invasiveness, COX-2 expression and matrix metalloproteinase (MMP) activity (12). COX-2 induces MMP-2 expression in breast cancer cells, facilitating tumor motility (13). MMP-2 expression has been associated with invasive carcinomas, given that it degrades type IV collagen (14).

Other molecular signaling cascades, including the Wnt/ $\beta$-catenin signaling pathway, exert effects on cell survival, polarity and migration. In the Wnt/ $\beta$-catenin signaling pathway binding of Wnt ligands to Frizzled receptors induces the release of $\beta$-catenin from a ubiquitinated cytoplasm complex, enhancing the translocation of $\beta$-catenin to the nucleus where it functions as a transcription factor (15). Numerous genes are targeted via $\beta$-catenin, which regulates tumor promotion and progression $(15,16)$. An association between COX-2/PGE2 and the $\mathrm{Wnt} / \beta$-catenin signaling pathway has been proposed in human breast cancer, where COX-2 expression is associated with increased $\beta$-catenin activity, promoting replicative immortality, invasion and metastasis (6).

Non-steroidal anti-inflammatory drugs (NSAIDs) inhibit COX activity, thus modulating PGE2 synthesis $(17,18)$. Since COX-2 serves a role in tumor progression, there is considerable evidence that NSAIDs may serve a role in inhibiting this process in mammary tissue $(19,20)$. Various NSAIDs, including piroxicam and meloxicam, have been studied in cancer. However, the preferential activity of meloxicam against COX-2 makes it an attractive therapeutic option compared 
with non-selective NSAIDs, because it may reduce side effects (21). Meloxicam is licensed for medium to long-term pain management in dogs, in which it induces only minor secondary effects (22). Few in vitro studies have determined the antiproliferative effect of meloxicam on mammary tumor cells, and they used high drug concentrations that cannot be translated in vivo $(23,24)$.

Therefore, the novel analysis of lower concentrations of meloxicam is required. $\mathrm{CF} 41 . \mathrm{Mg}$ is a canine mammary carcinoma cell line expressing mesenchymal-associated genes, including vimentin and $\mathrm{N}$-cadherin, and low levels of E-cadherin (25), indicating that these cells exhibit invasiveness and may be representative of high histological grade canine mammary tumors. The aim of the present study was to analyze the potential antiproliferative and anti-invasive effects of meloxicam on CF41.Mg canine mammary carcinoma cells.

\section{Materials and methods}

Cell culture. The CF41.Mg (ATCC ${ }^{\circledR}$ CRL-6232 ${ }^{\mathrm{TM}}$ ) cell line was purchased from the American Type Culture Collection (Manassas, VA, USA) and grown in Dulbecco's modified Eagle medium High Glucose (Hyclone; GE Healthcare Life Sciences, Logan, UT, USA), 10\% fetal bovine serum (FBS) (Hyclone; GE Healthcare Life Sciences), $100 \mathrm{U} / \mathrm{ml}$ penicillin $\mathrm{G}$, $100 \mu \mathrm{g} / \mathrm{ml}$ streptomycin sulfate and $2 \mathrm{mM}$ L-glutamine. The Madin-Darby Canine Kidney (MDCK) cell line was provided by Dr Victor Neira (Laboratory of Animal Virology, University of Chile, Santiago, Chile) and cultured in minimal essential medium (Gibco; Thermo Fisher Scientific, Inc., Waltham, MA, USA), 10\% FBS, $100 \mathrm{U} / \mathrm{ml}$ penicillin $\mathrm{G}$ and $100 \mu \mathrm{g} / \mathrm{ml}$ streptomycin sulfate. All cultures were maintained in a humidified atmosphere with $5 \% \mathrm{CO}_{2}$ at $37^{\circ} \mathrm{C}$. Evaluation of the growth kinetics of the cell lines under standard culture conditions was performed prior to starting the experiments.

Drug preparation. Meloxicam (Selleck Chemicals, Houston, TX, USA) and doxorubicin (Sigma-Aldrich; Merck KGaA, Darmstadt, Germany) were prepared in dimethyl sulfoxide (DMSO; $40 \mathrm{mg} / \mathrm{ml}$ ) and $\mathrm{PBS}(1 \mathrm{mg} / \mathrm{ml})$, respectively. Concentrations ranges were chosen on the basis of the average and maximum serum drug concentrations previously reported in dogs $(26,27)$. The final concentration of DMSO in the culture medium was $0.1 \%$ in all the experiments where meloxicam was used.

Indirect immunofluorescence. CF41.Mg and MDCK cells (1x10 $/$ well) were seeded and grown on sterile glass coverslips, and then fixed with absolute methanol. Cells were washed and blocked with PBS plus 2\% bovine serum albumin (Applichem GmbH, Darmstadt, Germany) for $30 \mathrm{~min}$ in a humidified chamber at room temperature. Subsequently, the cells were incubated with rabbit anti-COX-2 primary antibody clone SP21 (MA5-145; 1:50; Thermo Fisher Scientific, Inc.) at room temperature for $1 \mathrm{~h}$ as previously described $(28,29)$. Cells were then incubated with a goat anti-rabbit Alexa Fluor ${ }^{\circledR} 488$ secary antibody (1:500; Invitrogen; Thermo Fisher Scientific, Inc.; A11008) for $1 \mathrm{~h}$ at room temperature. Coverslips were mounted using Vectashield ${ }^{\circledR}$ mounting media with DAPI (Vector Laboratories, Inc., Burlingame, CA, USA). Finally, the samples were analyzed with an epifluorescence microscope fitted with a color charge-coupled device camera.

Western blot. Cells (2.5x105/100 mm dish) were seeded and exposed to $0.25 \mu \mathrm{g} / \mathrm{ml}$ meloxicam for $24-48 \mathrm{~h}$ and then lysed in RIPA Buffer with a Protease Inhibitor Cocktail added (both Cell Signaling Technology, Inc., Danvers, MA, USA), scraped and sonicated (3 cycles of 5 sec setting 10 of Branson sonifier 150; Danbury, CT, USA). After measuring protein concentration (Micro BCA Protein Assay kit, Thermo Fisher Scientific, Inc.), according to the manufacturer's indications, proteins (30 $\mu \mathrm{g}$ protein/lane) were resolved on $10 \%$ gels using SDS-PAGE. Proteins were then transferred onto polyvinylidene difluoride membranes, which were incubated overnight at $4^{\circ} \mathrm{C}$ with primary antibodies directed against the following proteins: COX-2 (1:200; Thermo Fisher Scientific, Inc.; MA5-145), $\beta$-catenin(1:1,000; BD Biosciences, Franklin Lakes, NJ, USA; 610154), phosphorylated (p)- $\beta$-catenin $(1: 1,000$; Cell Signaling Technology, Inc.; 9561) and MMP-2 (1:1,000; Invitrogen; Thermo Fisher Scientific, Inc.; 35-130-0Z). After washing, the membranes were incubated with anti-rabbit IgG $\mathrm{F}(\mathrm{ab})_{2}$ fragment (A6667) and anti-mouse IgG (Fab specific; A9917) peroxidase antibodies (1:5,000; Sigma-Aldrich; Merck $\mathrm{KGaA}$ ) for $1 \mathrm{~h}$ at room temperature. Protein bands were by enhanced chemiluminescence (Pierce ECL Western Blotting substrate; Thermo Fisher Scientific, Inc.; 32106). Relative levels of protein were determined by reprobing the membranes with anti- $\beta$-actin antibody (1:1,000; Abcam, Cambridge, UK; ab8226) for $1 \mathrm{~h}$ at room temperature. The bands obtained were analyzed with ImageJ software version $1.49 \mathrm{v}$ (National Institutes of Health, Bethesda, MD, USA).

Cell viability assay. CF41.Mg and MDCK cells were seeded at a density of $1.5 \times 10^{3}$ cells/well into 96-well plates, cultured for $24 \mathrm{~h}$ and then exposed to $0-25 \mu \mathrm{g} / \mathrm{ml}$ meloxicam alone or in combination with doxorubicin, a chemotherapy drug frequently used as an adjuvant treatment in dogs with mammary carcinoma. To evaluate synergism and sensitization, doxorubicin was added at the same time and after $24 \mathrm{~h}$, respectively. MDCK cells were exposed only to meloxicam as a non-tumor negative control. Control groups were cultured without meloxicam and doxorubicin, but the corresponding amount of DMSO was added to the medium. Following an incubation period of 24 and $48 \mathrm{~h}$, cell growth was measured using the MTS assay (CellTiter 96 ${ }^{\circledR}$ AQueous One Solution Cell Proliferation assay system; Promega Corporation, Madison, WI, USA), according to the manufacturer's instructions, with the absorbance at $490 \mathrm{~nm}$ determined using a microplate reader. Each experiment was performed 3 times in triplicate.

Flow cytometric apoptosis assay. CF41.Mg cells were cultured at a density of $4.5 \times 10^{5}$ per $100 \mathrm{~cm}^{2}$ dish. Cells treated with $0.25 \mu \mathrm{g} / \mathrm{ml}$ meloxicam or $500 \mathrm{ng} / \mathrm{ml}$ doxorubicin for $24 \mathrm{~h}$ were harvested with $0.25 \%$ trypsin-EDTA, washed and resuspended with PBS plus 2\% FBS. A FITC Annexin V Apoptosis Detection kit II (556419) was used according to the manufacturer's protocol (BD-Pharmingen, San Diego, CA, USA), to identify cells in the early phases of apoptosis. Early apoptotic cells were defined as propidium iodide (PI)/Annexin $\mathrm{V}^{+}$and late apoptotic cells were defined as $\mathrm{PI}^{+} /$Annexin $\mathrm{V}^{+}(30)$. Cell 
A

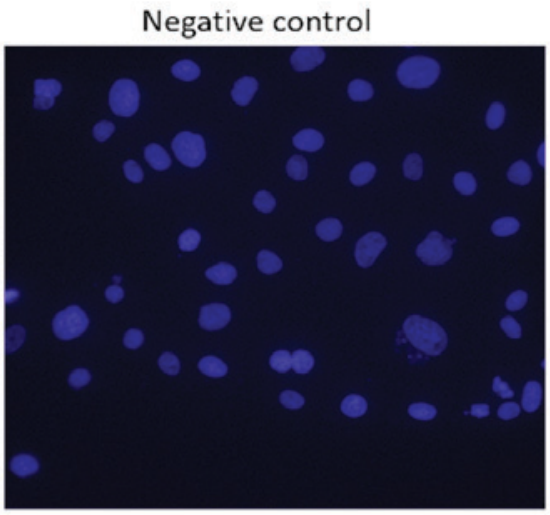

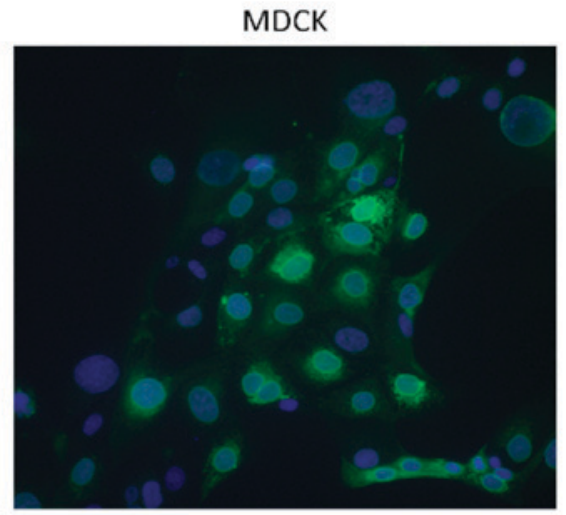

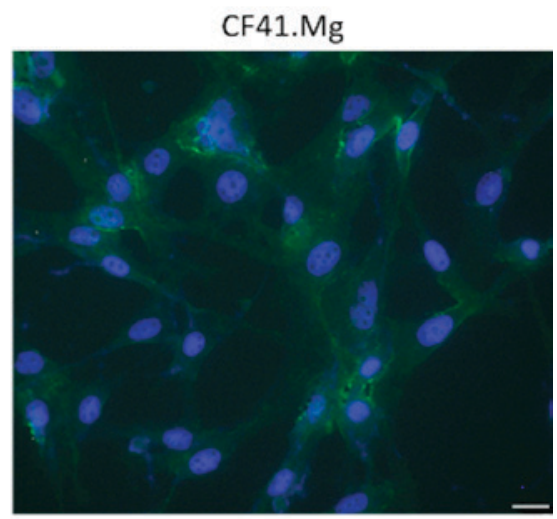

B
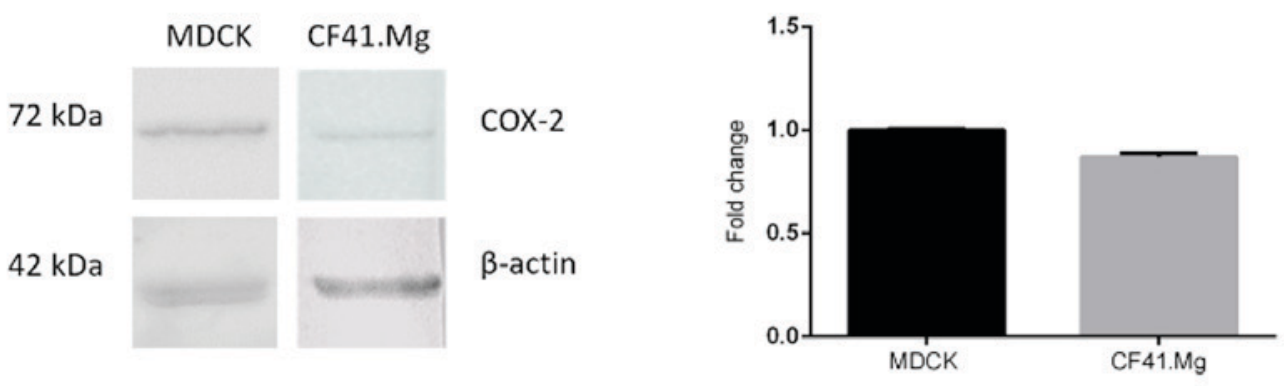

Figure 1. Expression of COX-2 in MDCK and CF41.Mg cells. (A) Representative immunofluorescence images of the (left panel) negative control, where the nuclei were visualized by DAPI, and COX-2 expression in MDCK and CF41.Mg cells respectively (central and right panel). Scale bar, $32 \mu \mathrm{m}$. (B) Representative Western blot of the expression of COX-2 in cell lysates, demonstrating a band at $72 \mathrm{kDa}$ in both cell lines. Results are representative of 3 independent experiments. COX, cycloooxgenase; MDCK, Madin-Darby Canine Kidney.

staining was measured using a FACSCalibur ${ }^{\mathrm{TM}}$ flow cytometer and the data was analyzed with FACSDiva ${ }^{\mathrm{TM}}$ software version 6.1.3 (both BD Biosciences). Experiments were run in triplicate and $\sim 10,000-20,000$ events were analyzed.

Cell migration assay. A scratch wound healing assay was performed to determine cell migration ability. CF41.Mg cells were seeded at a density of $1 \times 10^{4}$ cells/well into 24 -well plate and cultured until $80 \%$ confluent. Cell monolayers were scratched in a single line using a $200 \mu 1$ pipette tip, rinsed with PBS to remove cell debris and allowed to heal for 24 and $48 \mathrm{~h}$ at $37^{\circ} \mathrm{C}$ in the presence or absence of $0.25 \mu \mathrm{g} / \mathrm{ml}$ meloxicam. The average extent of wound closure was evaluated at 0,24 and $48 \mathrm{~h}$ by measuring the width of the wound, and images were captured using an inverted microscope. The migration area was calculated with ImageJ software version $1.49 \mathrm{v}$ using the following formula: Migration area $=$ (area of original wound-area of wound after healing)/area of original wound.

Matrigel cell invasion assay. Cell invasion was assayed using Transwell ${ }^{\circledR} 24$-well cell culture containing inserts with an $8 \mu \mathrm{m}$ pore size (BD Biosciences) coated with Matrigel. A total of $2.5 \times 10^{4} \mathrm{CF} 41 . \mathrm{Mg}$ cells were seeded into the upper chamber and incubated for $48 \mathrm{~h}$ in the presence of $0.25 \mu \mathrm{g} / \mathrm{ml}$ meloxicam and no FBS as previously described (20) against a gradient of 5\% FBS in the lower chamber. Non-invading cells on the upper side were wiped away with a cotton swab and the membrane was fixed with cold methanol $\left(-20^{\circ} \mathrm{C}\right)$ for $20 \mathrm{~min}$. DAPI was used to stain the invading cells, which were examined by epifluorescence microscopy, with 5 microscopic fields examined per insert.
Gelatin zymography. MMP-2 and -9 release was detected using gelatin zymography. After cells were exposed to meloxicam, the culture medium was removed, mixed with sample buffer (0.125 M Tris-HCl, pH 6.8, 10\% SDS, 8\% sucrose and $0.05 \%$ bromophenol blue) for $30 \mathrm{~min}$ at $25^{\circ} \mathrm{C}$. An electrophoretic run was then performed in a polyacrylamide gel copolymerized with $0.1 \%$ gelatin. Subsequently, the gels were washed with $2.5 \%$ Triton $\mathrm{X}-100$ and incubated for $18 \mathrm{~h}$ at $37^{\circ} \mathrm{C}$ in a buffer containing $50 \mathrm{mM}$ Tris $\mathrm{pH} 7.4,5 \mathrm{mM} \mathrm{CaCl}_{2}$ and $0.5 \mathrm{mM}$ $\mathrm{NaN}_{3}$. Finally, the gels were stained with Coomassie blue and examined.

ELISA detection of PGE 2 . CF41.Mg cells (2x104/well) were incubated in 24 -well plates at $37^{\circ} \mathrm{C}$ until $70 \%$ of confluence was reached. The culture medium was then changed and $0.25 \mu \mathrm{g} / \mathrm{ml}$ meloxicam was added. After 24 and $48 \mathrm{~h}$ incubation, supernatants were removed and centrifuged at $1,000 \times \mathrm{g}$ for $10 \mathrm{~min}$. The amount of PGE2 was determined using the Prostaglandin $\mathrm{E}_{2}$ ELISA kit-Monoclonal from Cayman Chemical Company (Ann Arbor, MI, USA) according the manufacturer's protocol as previously described (31).

Statistical analysis. One way analysis of the variance for the cell viability assays, a Student's $t$ test for the cell invasion, western blotting and annexin assays, and the Mann-Whitney $U$ test for the scrath plate assays were used to determine statistical significance between samples and their respective controls. $\mathrm{P}<0.05$ was considered to indicate a statistically significant difference. Data were analyzed with SPSS software (version 22; IBM SPSS, Armonk, NY, USA). 
A

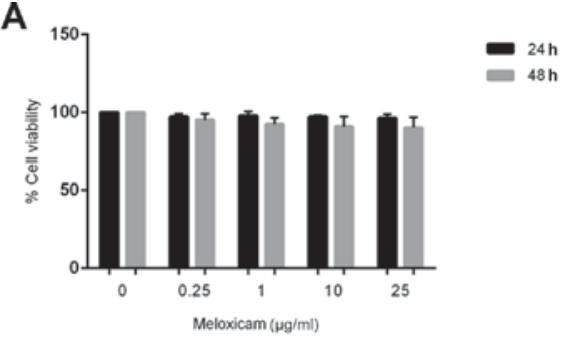

C

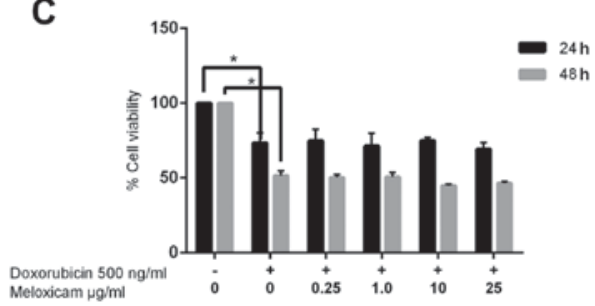

B
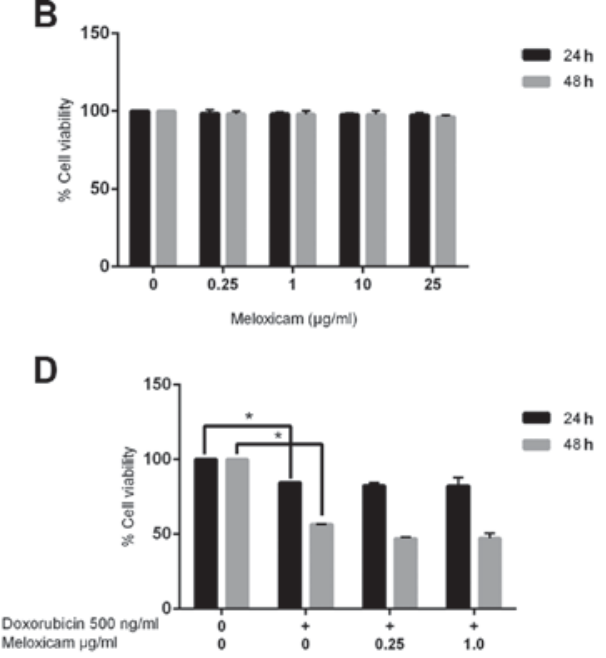

Figure 2. Cell viability following incubation with different concentrations of meloxicam and/or doxorubicin. (A) CF41.Mg and (B) MDCK cells were incubated for 24 and $48 \mathrm{~h}$ with meloxicam $(0-25 \mu \mathrm{g} / \mathrm{ml})$. The percentage of viable cells was determined by MTS assay. Control cells were treated with DMSO alone. (C) Viability of CF41.Mg cells incubated for 24 and $48 \mathrm{~h}$ with meloxicam $(0-25 \mu \mathrm{g} / \mathrm{ml})$ and $500 \mathrm{ng} / \mathrm{ml}$ doxorubicin. (D) CF41.Mg cells were incubated with meloxicam $(0-1 \mu \mathrm{g} / \mathrm{ml})$ and $24 \mathrm{~h}$ later $500 \mathrm{ng} / \mathrm{ml}$ doxorubicin was added. Cell viability was measured at 24 and $48 \mathrm{~h}$. Values are presented as the mean \pm standard deviation of $\geq 3$ independent experiments performed in triplicate. ${ }^{*} \mathrm{P}<0.05$.

\section{Results}

COX-2 is expressed in MDCK and CF41.Mg cells. MDCK and CF41.Mg cells were identified to exhibit COX-2 expression through immunofluorescence (Fig. 1A) and western blotting (Fig. 1B). COX-2 was localized in the cytoplasm of CF41.Mg cells and cytoplasm and perinucleus in MDCK cells (Fig. 1A). Western blot confirmed these results by revealing a band indicating COX-2 at $72 \mathrm{kDa}$. No notable differences in the relative expression of COX-2 between MDCK and CF41. $\mathrm{Mg}$ cells were observed (Fig. 1B). The growth kinetics of MDCK and CF41.Mg cells without drug treatment (exhibited an increase in total cell number of $\sim 3$-fold over a $48 \mathrm{~h}$ period (data not shown).

Meloxicam does not inhibit CF41.Mg cell viability. Since meloxicam is known to inhibit $\mathrm{COX}^{+}$tumor cells, its potential antineoplastic effect on CF41.Mg cells was examined using a cell viability assay. Meloxicam $(0.25-25 \mu \mathrm{g} / \mathrm{ml})$ did not decrease cell viability after 24 (100 vs. $96.33 \%$ viability in the control and $25 \mu \mathrm{g} / \mathrm{ml}$ meloxicam-treated cells, respectively) or $48 \mathrm{~h}$ (100 vs. $90.29 \%$ viability in the control and $25 \mu \mathrm{g} / \mathrm{ml}$ meloxicam-treated cells, respectively) of exposure (Fig. 2A). In order to evaluate the potential cytotoxic effects of meloxicam on $\mathrm{COX}^{+}$epithelial untransformed cells, the same assays were performed on MDCK cells. Similarly to in the tumor cells, meloxicam did not inhibit viability in MDCK cells (Fig. 2B).

Meloxicam does not have a synergistic effect with doxorubicin in CF41.Mg cells. To determine whether meloxicam could exert a synergistic effect with doxorubicin, the viability of CF41.Mg cells cultured in the presence of meloxicam and doxorubicin was examined. The viability of cells treated with meloxicam and doxorubicin was not significantly different compared with cells treated with doxorubicin alone (73.44 vs. $51.60 \%$ viability in cells exposed to doxorubicin alone at 24 and 48 h, respectively; 69.18 vs. $46.56 \%$ viability in cells exposed to doxorubicin and $25 \mu \mathrm{g} / \mathrm{ml}$ meloxicam at 24 and 48 h, respectively; Fig. 2C).

Meloxicam is not associated with chemosensitization in CF41.Mg cells. To determine whether chemosensitization was associated with meloxicam, meloxicam was administered $24 \mathrm{~h}$ prior to doxorubicin. No significant difference in cell viability was found using this method ( 84.45 vs. $56.53 \%$ viability in cells exposed to doxorubicin alone at 24 and $48 \mathrm{~h}$, respectively; 82.13 and $47.15 \%$ viability in cells exposed to doxorubicin and $25 \mu \mathrm{g} / \mathrm{ml}$ meloxicam at 24 and $48 \mathrm{~h}$, respectively; Fig. 2D). The following experiments were performed using the lower meloxicam concentration $(0.25 \mu \mathrm{g} / \mathrm{ml})$, in order to mimic the plasma concentration typically observed in dogs receiving oral meloxicam at therapeutic doses (26).

Meloxicam does not affect CF41.Mg cell apoptosis. The incubation of CF41.Mg cells in the presence of $0.25 \mu \mathrm{g} / \mathrm{ml}$ meloxicam did significantly not affect early and late apoptotic cell numbers after $24 \mathrm{~h}$ compared with the control group (Fig. 3).

Meloxicam decreases CF41.Mg cell migration and invasion. The migratory ability of CF41.Mg cells was analyzed following exposure to meloxicam. Cells exposed to $0.25 \mu \mathrm{g} / \mathrm{ml}$ meloxicam were significantly less migratory compared with the control cells at $24(\mathrm{P}=0.001)$ and $48(\mathrm{P}=0.002) \mathrm{h}$ in the wound healing assay, as indicated by a higher migration area (Fig. 4). Exposure to $0.25 \mu \mathrm{g} / \mathrm{ml}$ meloxicam also impaired the invasiveness of CF41.Mg cells in a Matrigel invasion assay. The number of invasive meloxicam-treated $(0.25 \mu \mathrm{g} / \mathrm{ml})$ cells was significantly lower compared with that of the control cells $(\mathrm{P}=0.025$; Fig. 5).

Meloxicam decreases MMP-2 expression in CF41.Mg cells. Based on the observed reduction in cell migration and invasion induced by meloxicam, the expression of 

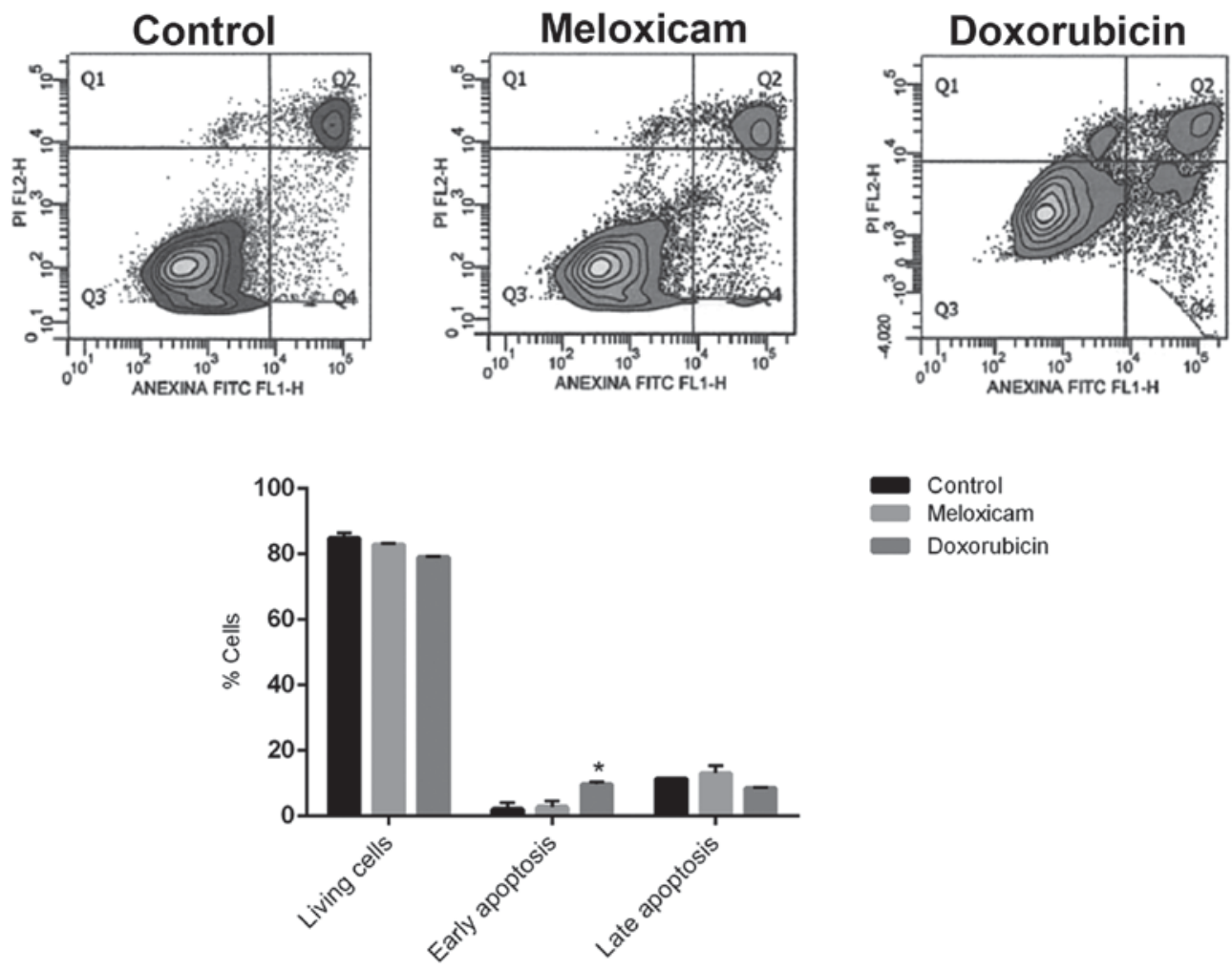

Figure 3. Meloxicam $(0.25 \mu \mathrm{g} / \mathrm{ml})$ has no effect on CF41.Mg cell apoptosis. Doxorubicin alone $(500 \mathrm{ng} / \mathrm{ml})$ was used as a positive control. A total of 3 independent experiments were performed and values are presented as the mean \pm standard deviation. Flow cytometry plots and analysis of the data are illustrated. ${ }^{*} \mathrm{P}<0.05$ vs. the control group.


Figure 4. Meloxicam $(0.25 \mu \mathrm{g} / \mathrm{ml})$ decreases the migration of CF41.Mg cells. Incubation with $0.25 \mu \mathrm{g} / \mathrm{ml}$ meloxicam for 24 and $48 \mathrm{~h}$ inhibited the migration of cells compared with the DMSO-treated control cells in a wound healing assay. A total of 6 repeats were performed and results are presented as the mean \pm standard deviation. Representative images of the wound healing assay and quantification if the results are presented. Scale bar, $90 \mu \mathrm{m}$. ${ }^{*} \mathrm{P}<0.05 \mathrm{vs}$. the control group. 

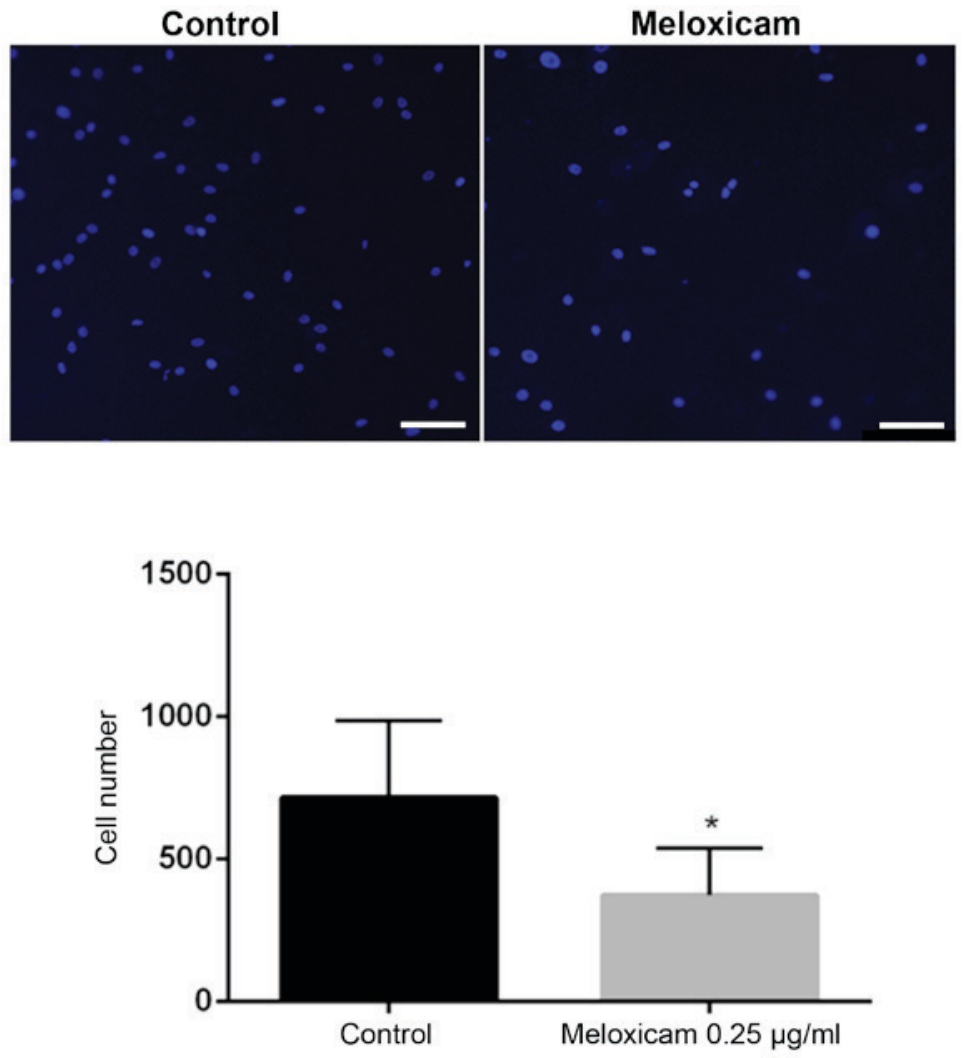

Figure 5. Meloxicam $(0.25 \mu \mathrm{g} / \mathrm{ml})$ decreases the invasion of CF41.Mg cells. The invasive cells were counted in 3 independent Matrigel invasion experiments and the results are presented as the mean number of invading cells \pm standard deviation. Representative microphotographs and a graph of the results are presented. Scale bar, $64 \mu \mathrm{m} .{ }^{*} \mathrm{P}<0.05$ vs. the control group.

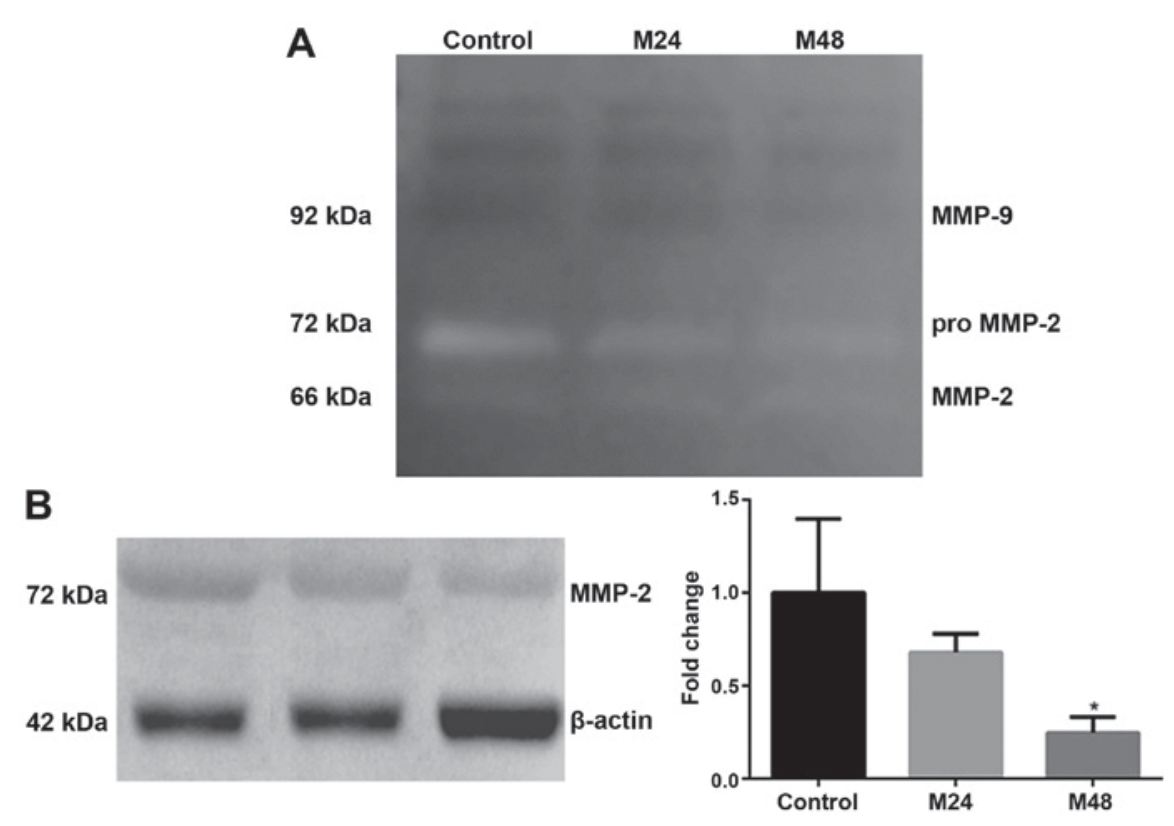

Figure 6. Meloxicam $(0.25 \mu \mathrm{g} / \mathrm{ml})$ increases the activity and expression of MMP-2 in CF41.Mg cells. (A) Representative gelatin zymography image of MMP-2 and 9. (B) Representative Western blot and respective histogram showing the expression of MMP-2. Values are expressed as mean \pm SD and at least three independent experiments were performed. ${ }^{*} \mathrm{P}<0.05$ vs. the control group. M24, meloxicam treatment for $24 \mathrm{~h}$; M48, meloxicam treatment for $48 \mathrm{~h}$.

invasion-promoting molecules in response to meloxicam was investigated. The release of MMP-2 and -9 into the culture medium was detected through their gelatinase activity by gelatin zymography. This was detected in the presence and absence of meloxicam. As illustrated in Fig. 6A, only
MMP-2 activity was detected in the supernatants studied. Meloxicam reduced MMP-2 gelatinase activity at 24 and $48 \mathrm{~h}$, where a stronger intensity of gelatinolytic band was observed in absence of meloxicam. Because this measurement of activity cannot be objectively quantifiable, these 

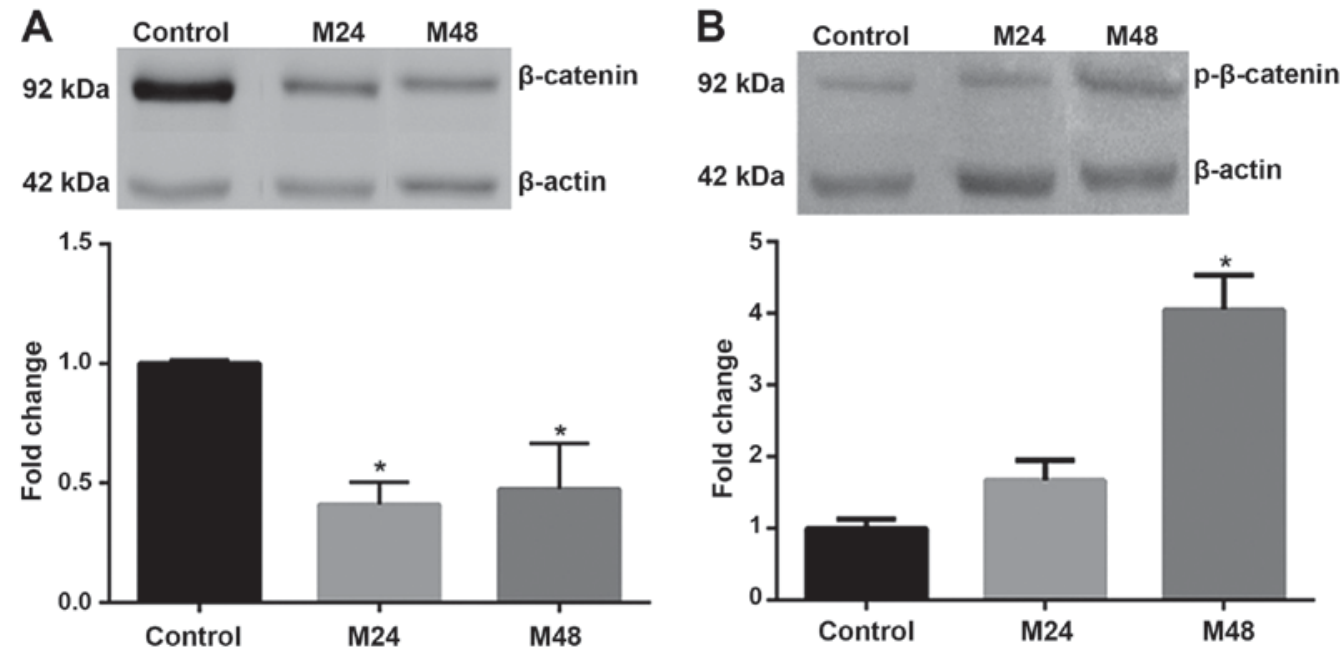

Figure 7. Meloxicam $(0.25 \mu \mathrm{g} / \mathrm{ml})$ increases $\beta$-catenin expression in CF41.Mg cells. Representative western blots and quantification of (A) total $\beta$-catenin and (B) $\mathrm{p}$ - $\beta$-catenin. Values are presented as the mean \pm standard deviation of $\geq 3$ independent experiments. ${ }^{*} \mathrm{P}<0.05$ vs. the control group. p, phosphorylated; M24, meloxicam treatment for $24 \mathrm{~h}$; M48, meloxicam treatment for $48 \mathrm{~h}$.

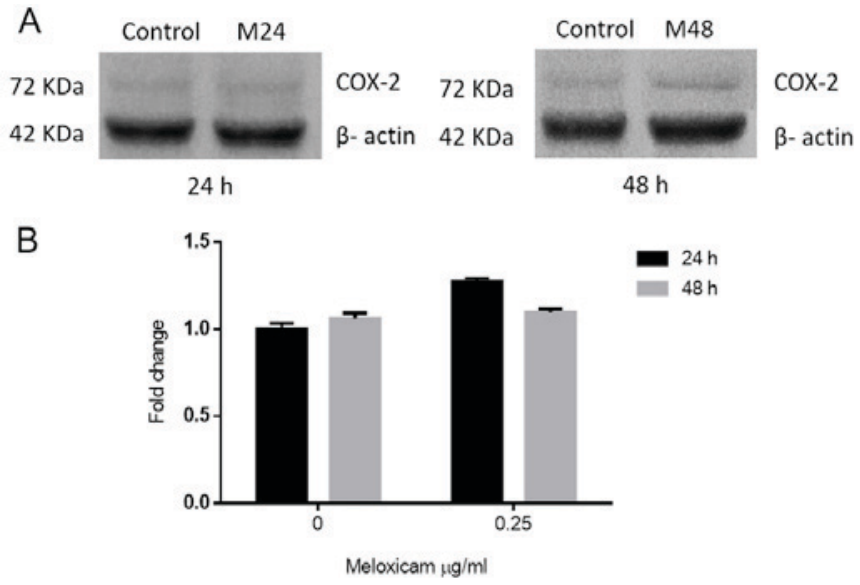

Figure 8. Meloxicam $(0.25 \mu \mathrm{g} / \mathrm{ml})$ does not affect COX-2 expression in CF41.Mg cells. (A) Representative western blots showing the expression of COX-2 in CF41.Mg cells for 24 (left blot) and $48 \mathrm{~h}$ (right blot) and (B) quantification of COX-2 expression. Values are presented as the mean \pm standard deviation of 3 independent experiments.

results were confirmed through western blotting, where meloxicam induced a significant decrease in the expression of MMP-2 at $48 \mathrm{~h}(\mathrm{P}=0.013$; Fig. 6B).

Meloxicam increases $\beta$-catenin phophorylation in CF41.Mg cells. The association between meloxicam and the COX-2 signaling pathway was investigated. A functional interaction between COX- 2 and $\beta$-catenin has been suggested in certain types of cancer, where MMPs could act as mediators $(6,17)$. Therefore, the levels of total and $\mathrm{p}$ forms of $\beta$-catenin in response to meloxicam were analyzed. A significantly lower expression of total $\beta$-catenin was observed in CF41.Mg cells incubated with meloxicam for 24 and 48 h compared with the control group $(\mathrm{P}<0.0001$ and $\mathrm{P}=0.014$, respectively; Fig. 7A). In addition, an increased expression of $\mathrm{p}-\beta$-catenin was detected in CF41.Mg cells incubated with meloxicam for $24 \mathrm{~h}(\mathrm{P}=0.074)$, which was significant at $48 \mathrm{~h}(\mathrm{P}=0.009$; Fig. 7B).
Meloxicam does not affect COX-2 expression in CF41.Mg cells. To evaluate whether meloxicam affects COX-2 expression in CF41.Mg cells, COX-2 protein levels in the absence and presence of $0.25 \mu \mathrm{g} / \mathrm{ml}$ of meloxicam, at 24 and $48 \mathrm{~h}$, were compared. No significant difference in the expression of COX-2 was observed between any of the groups (Fig. 8). The amount of PGE2 in supernatants could not be determined, since all values were out of the curve provided by the ELISA kit, being too low to be detected by this method.

\section{Discussion}

Several previous studies have proposed that NSAIDs could be used as an anticancer drug or as part of a chemopreventive therapy. Zhong et al (32) recently suggested that the long-term use of aspirin may reduce the risk of breast cancer in humans. In veterinary medicine, a number of previous studies have evaluated the in vitro and in vivo effects of different NSAIDs on animal tumors, including canine mammary tumors. For example, etodolac, meloxicam and celecoxib have been identified to suppress canine mammary tumor cell growth in vitro (24). By contrast, piroxicam, a non-selective NSAID, has been demonstrated to trigger clinical partial remissions in dogs with mammary carcinoma $(33,34)$. Meloxicam is licensed for veterinary use and is widely utilized in the management of pain and inflammatory diseases; it is a potent NSAID of the enolic acid class of oxicam derivatives, which has exhibited a preference for COX-2 compared with COX-1 inhibition at therapeutic concentrations $(21,36)$. Due to its preferential COX-2 inhibitory capacity, meloxicam has a better gastric and renal safety profile compared with non-selective NSAIDs $(21,35,36)$.

Since COX-2 is associated with poor cancer prognosis, the antitumor effect of meloxicam has been studied in different canine tumor cells. Several previous studies have demonstrated that meloxicam induces a reduction in cell proliferation and/or increase in apoptosis at high concentrations, exceeding the physiological maximum serum levels $(23,24)$. For example, in canine mammary tumor cells, $100 \mu \mathrm{M}$ meloxicam was demonstrated to inhibit cell proliferation, but not induce 
apoptosis (24). By contrast, Knottenbelt et al (23) revealed that meloxicam (10-160 $\mu \mathrm{g} / \mathrm{ml})$ induced inhibition of cell proliferation and an increase in apoptosis in mammary carcinoma cells in a dose-dependent manner, with maximum inhibition observed at a dose of $160 \mu \mathrm{g} / \mathrm{ml}$.

Metastatic cancer cells exhibit high motility, typically observed when cell-cell adhesions are lost and resulting in increased invasiveness (4). Since CF41.Mg cells exhibit a mesenchymal phenotype with characteristic low expression of E-cadherin (25), they were used as an in vitro model to study the invasive potential of canine mammary carcinoma cells in the present study. In this the present study, meloxicam had no effect on proliferation or apoptosis. However, a lower dose of meloxicam was used in the present study in order to mimic the plasma concentration observed in dogs receiving the routinely therapeutic dose of $0.1 \mathrm{mg} / \mathrm{kg}$ (35). In addition, meloxicam was not demonstrated to augment the cytotoxic effect of doxorubicin, a chemotherapy drug frequently used as an adjuvant treatment in dogs with mammary carcinoma.

Notably, a low concentration of meloxicam $(0.25 \mu \mathrm{g} / \mathrm{ml})$ was identified to significantly inhibit $\mathrm{CF} 41 . \mathrm{Mg}$ cell migration and invasion in the present study. These results may be mechanistically associated with the reduced expression/ activity of MMP-2 observed. In accordance with these results, Larkins et al (37) demonstrated that various COX-2 inhibitors reduce motility, invasion and MMP expression in breast cancer cells. This group also reported a decreased MMP-2 expression with undetectable levels of pro- and active MMP-9 under basal conditions, similar to the observations of the present study. These results suggest that MMP-9 does not effect on the invasiveness of CF41.Mg cells, while MMP-2 does.

In the current study, exposure to meloxicam reduced total $\beta$-catenin expression while increasing its phosphorylation. These effects may induce the destabilization and degradation of $\beta$-catenin via the proteasome, resulting in less $\beta$-catenin available for nuclear translocation and transcription of target genes, as described by Hugo et al (6). Thus, it can be suggested that the anti-invasive effect of meloxicam on CF41.Mg cells is associated with enhanced $\beta$-catenin degradation.

No significant differences in the levels of COX-2 in response to $0.25 \mu \mathrm{g} / \mathrm{ml}$ meloxicam treated were observed in the present study, which is concordant with the results of previous studies $(24,38)$. This indicates that meloxicam does not alter COX-2 expression; however, it does not exclude its participation in regulating the activity of $\mathrm{COX}-2$.

It was expected that PGE2, a product of COX-2 activity, would be reduced in a dose-dependent manner following meloxicam treatment. However, PGE2 was not detected under the experimental conditions of the present study. A previous report of COX-2 expression and activity in CF41.Mg cells identified no production of PGE2, which is consistent with our results (39). In this regard, it has been suggested that the rapid metabolic inactivation of PGE2 in cancer cells may limit its detection (40), explaining these outcomes. Unfortunately, these findings prevent the determination of whether the effects of meloxicam are dependent on COX-2 activity.

The PG signaling pathway is not the only mechanism of detecting inhibitory activity associated with meloxicam and other NSAIDs, as the antiproliferative effects were observed also in COX-negative cells lines (41). Several inhibitors of COX-2 have been identified to inhibit carbonic anhydrase (42), which is associated with tumor malignancy in breast cancer (43). This potential association should be explored in future studies to elucidate the COX-2-independent anti-invasive effects of meloxicam on CF41.Mg cells. There are numerous COX inhibitors available and it is necessary to extend these observations by analyzing their potential effect on the metastatic behavior of canine mammary tumor cells at in vivo concentrations.

In conclusion, the results of the present study demonstrate that meloxicam has no effect on the proliferation or apoptosis of CF41.Mg cells. In addition, the present study identified that meloxicam while significantly reduces $\mathrm{CF} 41 . \mathrm{Mg}$ cell invasion, at least in part by decreasing MMP-2 secretion and enhancing the degradation of $\beta$-catenin. Thus, meloxicam at low concentration of $0.25 \mu \mathrm{g} / \mathrm{ml}$, has an anti-invasive effect in canine mammary carcinoma cells, suggesting that meloxicam has a potential adjunctive therapeutic application, which could be useful in controlling the invasion and metastasis of canine mammary carcinomas.

\section{Acknowledgements}

The present study was supported by the Universidad Andres Bello (grant no. DI-425-13/I). The authors would like to thank Ms. Valeska Simon, Dr Christian Hidalgo, Dr Caroll Stoore and Dr María Pía García for their technical assistance.

\section{References}

1. Arenas C, Peña L, Granados-Soler JL and Pérez-Alenza MD: Adjuvant therapy for highly malignant canine mammary tumours: Cox-2 inhibitor versus chemotherapy: A case-control prospective study. Vet Rec 179: 125, 2016.

2. Torres CG, Pino AM and Sierralta WD: A cyclized peptide derived from alpha fetoprotein inhibits the proliferation of ER-positive canine mammary cancer cells. Oncol Rep 21: 1397-1404, 2009.

3. Cao Y and Prescott SM: Many actions of cyclooxygenase-2 in cellular dynamics and in cancer. J Cell Physiol 190: 279-286, 2002.

4. Hanahan D and Weinberg RA: Hallmarks of cancer: The next generation. Cell 144: 646-674, 2011.

5. Williams CS, Mann M and DuBois RN: The role of cyclooxygenases in inflammation, cancer, and development. Oncogene 18: 7908-7916, 1999.

6. Hugo HJ, Saunders C, Ramsay RG and Thompson EW: New insights on COX-2 in chronic inflammation driving breast cancer growth and metastasis. J Mammary Gland Biol Neoplasia 20: 109-119, 2015.

7. Soslow RA, Dannenberg AJ, Rush D, Woerner B, Khan KN, Masferrer J and Koki AT: COX-2 is expressed in human pulmonary, colonic, and mammary tumors. Cancer 89: 2637-2645, 2000.

8. Khan KN, Knapp DW, Denicola DB and Harris RK: Expression of cyclooxygenase-2 in transitional cell carcinoma of the urinary bladder in dogs. Am J Vet Res 61: 478-481, 2000.

9. Lavalle GE, De Campos CB, Bertagnolli AC and Cassali GD: Canine malignant mammary gland neoplasms with advanced clinical staging treated with carboplatin and cyclooxygenase inhibitors. In Vivo 26: 375-379, 2012.

10. Doré M, Lanthier I and Sirois J: Cyclooxygenase-2 expression in canine mammary tumors. Vet Pathol 40: 207-212, 2003.

11. Queiroga FL, Alves A, Pires I and Lopes C: Expression of COX-1 and COX-2 in canine mammary tumors. J Comp Pathol 136: 177-185, 2007.

12. Rozic JG, Chakraborty C and Lala PK: Cyclooxygenase inhibitors retard murine mammary tumor progression by reducing tumor cell migration, invasiveness and angiogenesis. Int $\mathrm{J}$ Cancer 93: 497-506, 2001. 
13. Lee KY, Kim YJ, Yoo H, Lee SH, Park JB and Kim HJ: Human brain endothelial cell-derived COX-2 facilitates extravasation of breast cancer cells across the blood-brain barrier. Anticancer Res 31: 4307-4313, 2011.

14. Stetler-Stevenson WG: Type IV collagenases in tumor invasion and metastasis. Cancer Metastasis Rev 9: 289-303, 1990.

15. Roarty K and Rosen JM: Wnt and mammary stem cells: Hormones cannot fly wingless. Curr Opin Pharmacol 10: 643-649, 2010.

16. Pang LY and Argyle D: Cancer stem cells and telomerase as potential biomarkers in veterinary oncology. Vet J 185: 15-22, 2010.

17. Dempke W, Rice C, Grothey A and Schmoll HJ: Cyclooxygenase-2: A novel target for cancer chemotherapy? J Cancer Res Clin Oncol 127: 411-417, 2001.

18. Shaheen NJ, Straus WL and Sandler RS: Chemoprevention of gastrointestinal malignancies with nonsteroidal antiinflammatory drugs. Cancer 94: 950-963, 2002.

19. Sonzogni-Desautels K, Knapp DW, Sartin E and Doré M: Effect of cyclooxygenase inhibitors in a xenograft model of canine mammary tumours. Vet Comp Oncol 9: 161-171, 2011.

20. Pang LY, Argyle SA, Kamida A, Morrison KO and Argyle DJ: The long-acting COX-2 inhibitor mavacoxib (Trocoxil ${ }^{\mathrm{TM}}$ ) has anti-proliferative and pro-apoptotic effects on canine cancer cell lines and cancer stem cells in vitro. BMC Vet Res 10: 184, 2014.

21. Streppa HK, Jones CJ and Budsberg SC: Cyclooxygenase selectivity of nonesteroidal anti-inflammatory drugs in canine blood. Am J Vet Res 63: 91-94, 2002.

22. Luna SP, Basilio AC, Steagall PV, Machado LP, Mountinho FQ, Takahira RK and Brandão CV: Evaluation of adverse effects of long-term oral administration of carprofen, etodolac, flunixin meglumine, ketoprofen, and meloxicam in dogs. Am J Vet Res 68: 258-264, 2007.

23. Knottenbelt C, Chambers G, Gault E and Argyle DJ: The in vitro effects of piroxicam and meloxicam on canine cell lines. J Small Anim Pract 47: 14-20, 2006.

24. Saito T, Tamura D and Asano R: Usefulness of selective COX-2 inhibitors as therapeutic agents against canine mammary tumors. Oncol Rep 31: 1637-1644, 2014.

25. Saito T, Dai T and Asano R: The hyaluronan synthesis inhibitor 4-methylumbelliferone exhibits antitumor effects against mesenchymal-like canine mammary tumor cells. Oncol Let 5: 1068-1074, 2013

26. Busch U, Schmid J, Heinzel G, Schmaus H, Baierl J, Huber C and Roth W: Pharmacokinetics of meloxicam in animals and the relevance to humans. Drug Metab Dispos 26: 576-584, 1998.

27. Selting KA, Ogilvie GK, Gustafson DL, Long ME, Lana SE, Walton JA, Hansen RA, Turner AS, Laible I and Fettman MJ: Evaluation of the effects of dietary n-3 fatty acid supplementation on the pharmacokinetics of doxorubicin in dogs with lymphoma. Am J Vet Res 67: 145-151, 2006.

28. Lavalle GE, Bertagnolli AC, Tavares WL and Cassali GD COX-2 expression in canine mammary carcinomas: Correlation with angiogenesis and overall survival. Vet Pathol 46: 1275-1280, 2009.

29. Prada J, Queiroga FL, Gregório H and Pires I: Evaluation of cyclooxygenase-2 expression in canine mast cell tumours. J Comp Pathol 147: 31-36, 2012.
30. Aubry J, Blaecke A, Lecoanet-Henchoz S, Jeannin P, Herbault N, Caron G, Moine V and Bonnefory JY: Annexin V used for measuring apoptosis in the early events of cellular cytotoxicity. Cytometry 37: 197-204, 1999

31. Tamura D, Saito T, Murata K, Kawashima M and Asano R: Celecoxib exerts antitumor effects in canine mammary tumor cells via COX-2-independent mechanisms. Int J Oncol 46: 1393-1404, 2015.

32. Zhong S, Zhang X, Chen L, Ma T, Tang J and Zhao J: Association between aspirin use and mortality in breast cancer patients: A meta-analysis of observational studies. Breast Cancer Res Treat 150: 199-207, 2015.

33. Knapp DW, Richardson RC, Bottoms GD, Teclaw R and Chan TC: Phase I trial of piroxicam in $62 \mathrm{dogs}$ bearing naturally occurring tumours. Cancer Chemother Pharmacol 29: 214-218, 1992.

34. De M Souza CH, Toledo-Piza E, Amorin R, Barboza A and Tobias KM: Inflammatory mammary carcinoma in 12 dogs: Clinical features, cyclooxygenase- 2 expression, and response to piroxicam treatment. Can Vet J 50: 506-510, 2009.

35. Montoya L, Ambros L, Kreil V, Bonafine R, Albarellos G, Hallu R and Soraci A: A pharmacokinetic comparison of meloxicam and ketoprofen following oral administration to healthy dogs. Vet Res Commun 28: 415-428, 2004

36. Kay-Mugford P, Benn S, LaMarre J and Conlon P: In vitro effects of nonsteroidal anti-inflammatory drugs on cyclooxygenase activity in dogs. Am J Vet Res 61: 802-810, 2000.

37. Larkins TL, Nowell M, Singh S and Sanford GL: Inhibition of cyclooxygenase-2 decreases breast cancer cell motility, invasion and matrix metalloproteinase expression. BMC Cancer 6: 181, 2006.

38. Wolfesberger B, Hoelzl C, Walter I, Reider GA, Fertl G, Thalhammer JG, Skalicky M and Egerbacher M: In vitro effects of meloxicam with or without doxorubicin on canine osteosarcoma cells. J Vet Pharmacol Ther 29: 15-23, 2006.

39. Brunelle M, Sartin EA, Wolfe LG, Sirois J and Doré M: Cyclooxygenase-2 expression in normal and neoplastic canine mammary cell lines. Vet Pathol 43: 656-666, 2006.

40. Schrey MP and Patel KV: Prostaglandin E2 production and metabolism in human breast cancer cells and breast fibroblasts. Regulation by inflammatory mediators. Br J Cancer 72 : 1412-1419, 1995.

41. Waskewich C, Blumenthal RD, Li H, Stein R, Goldenberg DM and Burton J: Celecoxib exhibits the greatest potency amongst cyclooxygenase (COX) inhibitors for growth inhibition of COX-2 negative hematopoietic and epithelial cell lines. Cancer Res 62: 2029-2033, 2002.

42. De Monte C, Carradori S, Gentili A, Mollica A, Trisciuoglio D and Supuran CT: Dual cyclooxygenase and carbonic anhydrase inhibition by nonsteroidal anti-inflammatory drugs for the treatment of cancer. Curr Med Chem 22: 2812-2818, 2015.

43. Chu CY, Jin YT, Zhang W, Yu J, Yang HP, Wang HY, Zhang ZJ, Liu XP and Zou Q: CA IX is upregulated in $\mathrm{CoCl} 2$-induced hypoxia and associated with cell invasive potential and a poor prognosis of breast cancer. Int J Oncol 48: 271-280, 2016. 